\title{
A FURTHER NOTE ON FEDERAL CAUSES OF ACTION
}

\author{
John F. Preis* \\ INTRODUCTION
}

It's hard to disagree with someone who mostly agrees with you, but I will try my best. In his review of my article addressing the relationship between the federal cause of action and rights, remedies, and jurisdiction, 1 Professor Lumen Mulligan pays my article several compliments. ${ }^{2}$ In this, I fully agree with him. But the wise Professor Mulligan also attempts to point out some errors in my analysis. On these points, I must mostly voice my disagreement.

Let me begin by very briefly recounting the gist of my article. In the article, I attempt to define a federal cause of action, and describe its relationship to federal rights, remedies and subject matter jurisdiction. Federal courts throw these terms around so often - and so erraticallythat considerable confusion has arisen. ${ }^{3}$ Confusion between terms is not necessarily a major problem (our society can generally survive without knowing the difference between a sofa and couch), but when such confusion finds its way into the law, serious problems arise. If a cause of action is deemed "remedial," for example, then courts will tend to make causes of action available to the degree that remedies would be available. ${ }^{4}$ In contrast, if causes of action are "jurisdictional," courts will tend to make them available according to jurisdictional rules. ${ }^{5}$ The upshot here is that the availability of a federal cause of action will be affected by how we define it. It is thus essential to define it correctly and my article is an effort to do so.

In the article, I argue that federal causes of action ought to be treated as (1) distinct from substantive rights, (2) synonymous with the availability of a remedy (but not whether a remedy will in fact issue) and (3) distinct from subject matter jurisdiction (unless Congress instructs otherwise). ${ }^{6}$ This thesis is built principally on a historical recounting of the cause of action from eighteenth century England to twenty-first century America. ${ }^{7}$ In taking an historical approach, I did not

* Professor of Law, University of Richmond School of Law.

1. John F. Preis, How the Federal Cause of Action Relates to Rights, Remedies, and Jurisdiction, 67 FLA. L. REV. 849 (2015).

2. Lumen N. Mulligan, We Should Use 'Cause of Action' More Carefully: A Review of John F. Preis, How the Federal Cause of Action Relates to Rights, Remedies and Jurisdiction, 67 FLA. L. REV. F. 42 (2015).

3. See Preis, supra note 1, at 854-64 (tracing the relationship of federal causes of action and rights, remedies, and jurisdiction).

4. See id. at 868 .

5. See id. at 870 .

6. Id. at $852-53$.

7. Id. at 852 . 
mean to argue that federal courts are bound to adhere to centuries-old conceptions of the cause of action. I merely used history to show why the cause of action has taken on various identities and, further, why these identities have changed over time. By closely attending to these changes, we can better determine whether linguistic changes signal substantive changes in doctrine, or are simply loose language.

Professor Mulligan, as I noted at the outset, generally applauds my diagnosis of the problem as well my chosen remedy, but he does take issue with my conclusions in two respects. First, he disputes my claim that the cause of action can be jurisdictional in sovereign immunity cases. ${ }^{8}$ Second, he disputes my claim that "the cause of action has been, and remains today, remedy specific." I will address each of his concerns in turn.

\section{The CAUSE OF ACTION, JuRISDICTION AND SOVEREIGN IMMUNiTy}

Although I briefly outlined my arguments above, it is necessary to explore my jurisdictional claims in a bit more detail before responding to Professor Mulligan. In my view, the federal cause of action should generally be considered distinct from jurisdiction. Thus, a plaintiff who alleges a violation of federal law but lacks a federal cause of action should have her claim dismissed on the merits, not dismissed for lack of jurisdiction. ${ }^{10}$ This standard rule is subject to an exception, however. I explained in the article that the existence (or not) of sovereign immunity - a jurisdictional matter-often turns on the existence (or not) of a cause of action. ${ }^{11}$ For instance, if Congress creates a right by enacting Statute $\mathrm{X}$ and then declares that "persons aggrieved by violations of Statute X may sue any state responsible for the violation," federal courts typically conclude that a state's sovereign immunity has been abrogated. ${ }^{12}$ This is reasonable in my view because, if sovereign immunity is an immunity from suit (not just liability), then a statute that authorizes a suit signals Congress's desire that states have no immunity with regard to Statute $X$. The same logic applies when a state consents to suit (usually in exchange for federal funds) ${ }^{13}$ or the federal

8. Mulligan, supra note 2, at 43.

9. Id. at 44 (quoting Preis, supra note 1 , at 886 ).

10. See Preis, supra note 1, at 887-90.

11. Id. at 890-92 (discussing the relationship between federal causes of action and sovereign immunity).

12. See, e.g., United States v. Georgia, 546 U.S. 151, 159 (2006) (holding that, "insofar as Title II [of the Americans with Disabilities Act] creates a private cause of action for damages against the States for conduct that actually violates the Fourteenth Amendment, Title II validly abrogates state sovereign immunity.").

13. See Sossamon v. Texas, 131 S. Ct. 1651, 1657-58 (2011) (analyzing scope of cause of action against Texas to determine whether Texas waived its sovereign immunity). 
government waives its own sovereign immunity. ${ }^{14}$ In both of those situations, it is the cause of action that signifies the consent or waiver.

Based on these circumstances, I criticized the Supreme Court's frequent assertion that the "cause of action does not implicate subjectmatter jurisdiction." 15 In cases of abrogation, consent or waiver, the existence of sovereign immunity (and thus subject matter jurisdiction) often does turn on the existence of a cause of action. ${ }^{16}$ To be sure, the creation of a cause of action is not the only way that sovereign immunity might disappear, but it is a common way and Congress, of course, is free to dictate whether and how the two concepts shall be linked.

Mulligan sees the matter differently. For him, the cause of action, to the extent it sometimes overlaps with sovereign immunity, does not render the cause of action jurisdictional. This is because sovereign immunity is, in his words, "a defense with jurisdictional implications.",17 What I take Mulligan to be arguing is that, because causes of action are normally plead by plaintiffs, and the absence of sovereign immunity is not normally plead by plaintiffs, it follows that the two are not related.

Mulligan is correct that sovereign immunity is a defense that, if accepted by the court, will result in a jurisdictional dismissal. I believe he is incorrect, however, in insisting that the defensive context in which the immunity issue is raised means that that issue is not related to the cause of action. It is irrelevant, in my mind, how the sovereign immunity issue arises.

Consider, for example, a suit against the federal government. To sue the government, one must locate a wavier of immunity. ${ }^{18}$ One such waiver is found at 5 U.S.C. $\S 702$. Importantly, $\S 702$ also creates a cause of action. The relevant language is as follows:

A person suffering legal wrong [owing to federal agency action] is entitled to judicial review thereof. An action in a court of the United States seeking relief other than money damages . . . shall not be dismissed nor relief therein be denied on the ground that it is against the United States ...

14. See Lane v. Pena, 518 U.S. 187, 191 (1996) (in damages action to enforce the Rehabilitation Act, analyzing the cause of action used to enforce the Act to determine whether the cause of action "establish[es] a waiver of the Federal Government's sovereign immunity against monetary damages awards for violations").

15. Verizon Md. Inc. v. Pub Serv. Comm'n of Md., 535 U.S. 635, 642-43 (2002).

16. Preis, supra note 1 , at 891 .

17. Mulligan, supra note 2, at 43.

18. See Preis, supra note 1, at 909.

19. 5 U.S.C. $\S 702$ (2012). 
Suppose that a plaintiff brings suit against a federal agency. The agency files a motion to dismiss making two arguments. First, the agency argues that the court lacks subject matter jurisdiction because the agency, as an arm of the federal government, is entitled to sovereign immunity. Second, the agency argues that the plaintiff's claim must be dismissed on the merits because she lacks a cause of action. The plaintiff responds to both arguments by pointing to a single provision: $\S$ 702. That section, the plaintiff argues, waives sovereign immunity by authorizing her to sue the government. In fact, the authorization of suit is how immunity has been waived. On these facts, the court should deny the government's motion to dismiss and explain that $\S 702$ defeats both arguments for dismissal. Because $\S 702$ provides the plaintiff with a cause of action and provides the court with jurisdiction, it follows that, in sovereign immunity cases at least, the cause of action can, and often does, implicate subject matter jurisdiction. This conclusion, moreover, is completely unaffected by the fact that the sovereign immunity issue was raised as a defense rather than plead by the plaintiff.

Of course, one could argue that referring to $\S 702$ as a "single provision" is artificial. The statutory provision, it might be said, actually contains two separate statements: The first statement, by authorizing "judicial review," creates a cause of action, and the second, by directing that such suits "shall not be dismissed," waives sovereign immunity. More to the point, if Congress were to separate the two provisions into $\S$ 702 and $\S 703$, one could hardly argue that the cause of action in $\S 702$ also created subject matter jurisdiction.

I agree, but this argument does not defeat my central claim, which is that Congress, if it desires, can make causes of action jurisdictional. Congress's frequent practice in the realm of sovereign immunity is to link the two, ${ }^{20}$ but the inquiry will always be one of statutory interpretation. Reasonable people can differ about whether the two provisions of $\S 702$ are inextricably linked or simply separate concepts couched in the same section. If the first provision ended in a semi colon or a comma, the connection between the two provisions might be strengthened. Similarly, if the second provision was never enacted, courts might reasonably conclude - as they have before - that the first provision implicitly addressed sovereign immunity on its own. ${ }^{21}$ One need not agree with any of these interpretations to agree with the core of

20. Preis, supra note 1 , at $890-92$.

21. See Bd. of Trs. of Univ. of Ala. v. Garrett, 531 U.S. 356, 374 (2001) (holding that sovereign immunity was offended by Congress's attempt, in the Americans with Disabilities Act, to "authorize private individuals to recover money damages against the States"); see also Lane v. Pena, 518 U.S. 187, 192 (1996) (analyzing the Rehabilitation Act's cause of action to determine whether "the Federal Government's [waiver of] sovereign immunity [was] unequivocally expressed in statutory text"). 
my claim, however; one need only accept that, at some point, the text will be clear enough for a court to conclude that a single provision both creates a cause of action and jurisdiction.

\section{The CAuse of Action And Remedies}

Professor Mulligan also takes issue with my claim about the relationship between the cause of action and remedies. ${ }^{22}$ In my article, I criticized the Court's frequent statement that "the question whether a litigant has a cause of action is analytically distinct and prior to what relief, if any, a litigant may be entitled to receive." ${ }^{, 23}$ In response to this, I demonstrated that when a federal court asks whether a cause of action exists, it is in fact asking whether a particular remedy is available. Take, for example, Bivens actions. ${ }^{24}$ When a court considers whether to imply a Bivens action, it is in fact asking whether a plaintiff ought to be able to obtain damages for the harm alleged. ${ }^{25}$ It is impossible to read the Court's Bivens cases and conclude that "what relief, if any, a litigant may be entitled to receive" has no role to play. ${ }^{26}$ Based on this and other examples, I argued that the "cause of action has been, and remains today, remedy-specific." 27 That is, "a plaintiff may have a cause of action for injunctive relief but not damages.",28

This claim got Mulligan's attention. He agrees that, in the field of constitutional rights, causes of action are often tied to a particular type of remedy. But he thinks my point is too strong when it comes to causes of action to enforce statutory rights. "[O]nce one ventures beyond the rarified air of constitutional torts," Mulligan argues, "one finds that the Court often applies the maxim [that when a] . . f federal statute provides for a general right to sue..., federal courts may use any available remedy to make good the wrong done."29 Mulligan's point, as I read it, is that causes of action are sometimes silent on which remedies can issue and that, when they are, courts can and do assume that they have the power to issue whichever remedy seems appropriate. If this is true, then it can hardly be said that causes of action are "remedy specific."

Mulligan is correct in part. He is undoubtedly correct that causes of action do not always specify a particular remedy and that, when the cause of action is silent on the matter of remedy, federal courts are left

22. Mulligan, supra note 2, at 44.

23. Davis v. Passman, 442 U.S. 228, 239 (1979) (internal quotation marks omitted).

24. Bivens v. Six Unknown Named Agents of Fed. Bureau of Narcotics, 403 U.S. 388 (1971).

25. Id. at 388 .

26. Davis, 442 U.S. at 239.

27. Preis, supra note 1 , at 886 .

28. Id.

29. Mulligan, supra note 2, at 44 (quoting Bell v. Hood, 327 U.S. 678, 684 (1946)). 
to determine on their own the appropriate remedy. Thus, to the extent that my article implies that every cause of action is remedy specific, I overstated the case. But I think Mulligan overstates his case as well. I do not think that the Court "often" finds statutory causes of action silent on the issue of which remedies are available. Indeed, I think that situation is quite uncommon.

Consider, for example, Sossamon v. Texas. ${ }^{30}$ The question presented in Sossamon was whether a plaintiff could pursue a damages action against a state for a violation of the Religious Land Use and Institutionalized Persons Act (RLUIPA). ${ }^{31}$ The case turned on the interpretation of the following cause or action: "A person may assert a violation of [RLUIPA] as a claim or defense in a judicial proceeding and obtain appropriate relief against a government."

The question for the Court was whether the words "appropriate relief" in the cause of action included damages. The plaintiff argued that a damages action was permissible because, as stated in Bell v. Hood, when a "federal statute provides for a general right to sue ..., federal courts may use any available remedy to make good the wrong done.",33 In other words, the plaintiff believed that the cause of action was silent on the issue of remedies.

The Court explicitly rejected that argument. The statute was not silent on the issue of remedies. ${ }^{34}$ Indeed, the statute explicitly spoke of remedies by authorizing "appropriate relief." Thus, the Court did not conclude it was free to "use any available remedy" but instead followed the text wherever it led. In this case, the Court reasoned that "the word 'appropriate' is inherently context-dependent" and further that " $t]$ he context here-where the defendant is a sovereign-suggests, if anything, that monetary damages are not 'suitable' or 'proper.'

Sossamon illustrates how a cause of action that does not explicitly mention damages or injunctive relief can still speak to those matters. Put differently, Sossamon shows how rarely a cause of action will be deemed silent on the issue of remedies. Causes of action that speak of "appropriate relief" are common and the Supreme Court has interpreted these causes of action with traditional tools of statutory interpretation, rather than assumed that they offer the court a blank slip to issue

30. 131 S. Ct. 1651 (2011).

31. Id. at 1655 .

32. 42 U.S.C. $\S 2000 \mathrm{cc}-2(\mathrm{a})$.

33. Bell v. Hood, 327 U.S. 678, 684 (1946)

34. Sossamon, $131 \mathrm{~S}$. Ct at 1651 (stating that a court's authority to issue any available remedy only arises when there is no text to interpret).

35. Id. at 1659. Absent waiver or abrogation, states are not suable in federal court for monetary relief. See Edelman v. Jordan, 415 U.S. 651, 672-73. (1974). 
whatever remedy it might conjure up. ${ }^{36}$

Of course causes of action may not always contain a textual reference to a particular form of relief. Implied causes of action, by their very nature, do not have a textual basis (though these are often remedy-specific nonetheless). ${ }^{37}$ And it is at least possible that Congress, instead of stating that a plaintiff "may bring suit for any appropriate relief," could simply state "may bring suit." This is why I stated at the outset that I "mostly" stand by my claim that causes of action are remedy specific. So while it is inappropriate to say that every federal cause of action portends the existence of specific type of remedy (or remedies), it is fair to say that this is true in the large majority of cases.

\section{CONCLUSION}

I have spent several pages disagreeing with Mulligan on some minor points. As I close, it is important to emphasize what we agree on, which is that the Supreme Court has not articulated a coherent conception of the federal cause of action. This failure has led to numerous problems, confusions, and doctrinal mistakes. Our hope is that scholarship on this issue - including not only my own, but his as well ${ }^{38}$ — will persuade jurists of the need for reform in this field.

36. See, e.g., Guidry v. Sheet Metal Workers Nat'1 Pension Fund, 493 U.S. 365, 374-75 (1990) (holding that a cause of action for "appropriate relief" provided by the LaborManagement Reporting and Disclosure Act did not permit the court to create a construction trust because it would violate "ERISA's prohibition on the alienation of pension benefits"); Mass. Mut. Life Ins. Co. v. Russell, 473 U.S. 134, 142, 144 (1985) (in ERISA case, holding that plaintiff may not recover certain compensatory and punitive damages even though the ERISA cause of action authorized suit for "appropriate relief"; to interpret the cause of action otherwise would render "superfluous the preceding clauses providing [other types of relief]"); Sch. Comm. of Town of Burlington v. Dep't of Educ. of Mass., 471 U.S. 359, 369 (1985) (holding that Education of the Handicapped Act's order that courts "grant such relief as [it] determines is appropriate" should be interpreted "in light of the purpose of the Act").

37. See Bivens v. Six Unknown Named Agents of Fed. Bureau of Narcotics, 403 U.S. 388 (1971) (creating a cause of action against federal officers only for monetary relief).

38. Lumen N. Mulligan, A Unified Theory of 28 U.S.C. $\$ 1331$ Jurisdiction, 61 VAND. L. REV. 1667 (2008). 